\title{
Correction to: Social media use disorder and loneliness: any association between the two? Results of a cross-sectional study among Lebanese adults
}

\author{
Lara Youssef ${ }^{1}$, Rabih Hallit ${ }^{2}$, Nelly Kheir ${ }^{3}$, Sahar Obeid ${ }^{4,5,6+}$ and Souheil Hallit ${ }^{2,6^{*+}}$
}

\section{Correction to: BMC Psychology (2020) 8:56 \\ https://doi.org/10.1186/s40359-020-00421-5}

Following publication of the original article [1], the authors identified a missing reference.

Hallit, S., Sacre, H., Haddad, C. et al. Development of the Lebanese insomnia scale (LIS-18): a new scale to assess insomnia in adult patients. BMC Psychiatry 19, 421 (2019). https://doi.org/10.1186/s12888-019-2406-y

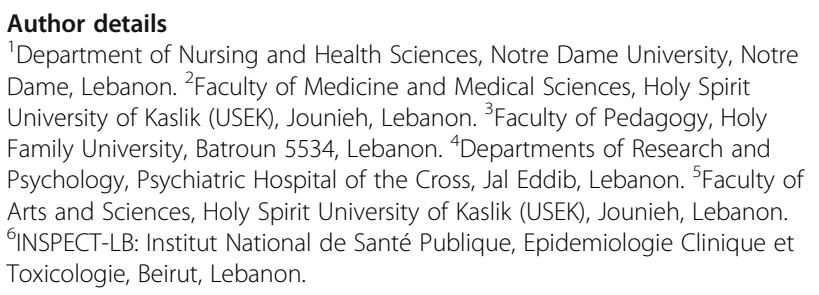

Published online: 21 July 2020

\section{Reference}

1. Youssef, et al. Social media use disorder and loneliness: any association between the two? Results of a cross-sectional study among Lebanese adults. BMC Psychology. 2020;8:56. https://doi.org/10.1186/s40359-02000421-5.

The original article can be found online at https://doi.org/10.1186/s40359020-00421-5.

* Correspondence: souheilhallit@hotmail.com

${ }^{\dagger}$ Sahar Obeid and Souheil Hallit contributed equally to this work.

${ }^{2}$ Faculty of Medicine and Medical Sciences, Holy Spirit University of Kaslik (USEK), Jounieh, Lebanon

${ }^{6}$ INSPECT-LB: Institut National de Santé Publique, Epidemiologie Clinique et Toxicologie, Beirut, Lebanon

Full list of author information is available at the end of the article

(c) The Author(s). 2020 Open Access This article is licensed under a Creative Commons Attribution 4.0 International License, which permits use, sharing, adaptation, distribution and reproduction in any medium or format, as long as you give appropriate credit to the original author(s) and the source, provide a link to the Creative Commons licence, and indicate if changes were made. The images or other third party material in this article are included in the article's Creative Commons licence, unless indicated otherwise in a credit line to the material. If material is not included in the article's Creative Commons licence and your intended use is not permitted by statutory regulation or exceeds the permitted use, you will need to obtain permission directly from the copyright holder. To view a copy of this licence, visit http://creativecommons.org/licenses/by/4.0/. The Creative Commons Public Domain Dedication waiver (http://creativecommons.org/publicdomain/zero/1.0/) applies to the data made available in this article, unless otherwise stated in a credit line to the data. 